\title{
Citizenship Education in Global Context
}

\author{
Graham Pike \\ University of Prince Edward Island
}

\begin{abstract}
Citing the need to choose a broader vision than that provided by the plethora of citizenship education models currently in circulation, Pike challenges the fundament of GCE with a view to exposing some tensions and difficulties inherent in its implementation within schools. Following an exploration of six such tensions and difficulties, many of which are central to GCE, Pike suggests possible dimensions of an ethos of global citizenship - a set of moral principles and codes of conduct - that is global in scope all the while recognizing that citizenship will continue, for the foreseeable future, to be national in practice.
\end{abstract}

The idea that citizenship education should be conceptualized within a global context has been pursued, in many different ways, for more than half a century. In the UK, the League of Nations Union, the Council for Education in World Citizenship, and the Parliamentary Group for World Government all vigorously promoted the concept at various times during the twentieth century (Heater, 1984). From the 1960s, the development education, global education and world studies movements made significant contributions, especially in teacher education and curriculum development, in several countries, including Canada. Funding from the Canadian International Development Agency, which established global education projects in eight out of ten provinces between 1987 and 1995, fomented a groundswell of interest among teachers which, though lacking co-ordination and leadership, has served to lay the foundation for a renewed interest in global citizenship education (Mundy, 2007). It is not the goal of this paper to reiterate the already well documented arguments for global citizenship education; rather, my desire is to stimulate further debate by examining some problems that global citizenship education has encountered in the past, or may face today, and to suggest some possible ways forward. The time is right for such

Graham Pike is Professor and Dean of Education at the University of Prince Edward Island, and can be reached at gpike@upei.ca 
discussion: the progress - and the setbacks - experienced by development and global educators over the past thirty years can be effectively exploited by those interested in choosing a broader vision from among the plethora of citizenship education models that are currently in circulation. However, it is worth trying to understand the difficulties inherent in that vision so as to develop more effective strategies for the future.

In the current debates on the nature and purpose of citizenship education, a range of broader visions of citizenship have been proposed by educators from several countries. Among these are Heater's concept of the "multiple citizen" (Heater, 1990); Selby's description of "plural and parallel citizenship" (Selby, 2000); and Hébert's construction of "a new flexible citizenship" (Hébert, 1997). From the field of multicultural education, Lynch (1992) suggests that "education for active global democracy" is the real challenge for educators; and Banks (2001) depicts "globalism and global competency" as the sixth and ultimate stage in individuals' development of cultural identity. From a peace education perspective comes Boulding's idea of "building a global civic culture" (Boulding, 1988). Dower (2003) provides a thoughtful articulation of the concept of global citizenship from a philosophical standpoint and Noddings (2005) expands her notion of "caring" to include peace, social justice, and environmental protection at the global level. Two relatively full, research-based models of global citizenship education are described by Griffith (1998) and by Cogan and Derricott (1998), who prefer the term "multidimensional citizenship." Non-governmental organizations, including Oxfam UK (2006), the Canadian Council for International Co-operation (1996), and the Bahá'í International Community (1993), have also published their visions of global citizenship. It is not my intention here to explore the merits of these various conceptions, merely to note that ideas for global citizenship education abound and are derived from various educational standpoints.

\section{The Problematic Concept of Global Citizenship}

A fundamental principle of global citizenship models is that an individual's awareness, loyalty, and allegiance can and should extend beyond the borders of a nation to encompass the whole of humankind, an idea variously termed "post-nationalist consciousness" (Ignatieff, 1993) or "the cosmopolitan ideal" (Kingwell, 2000), or the development of a "global moral community" (Dower, 2003). This is the bedrock upon which other dimensions of global citizenship, such as rights, responsibilities and active participation, are built. It is frequently argued that such consciousness is no more than due acknowledgment of the realities that link all humans in an interlocking network of global systems. As Giddens (cited in Griffith, 1998, p. 37) puts it, "the level 
of time-space distanciation introduced by high modernity is so extensive that, for the first time in human history, 'self' and 'society' are interrelated in a global milieu." It is a principle that underlies much of my own, and others', work in global education and upon which associated curriculum and school reforms have been founded. My goal here is to critique this fundament of global citizenship, not in terms of its theoretical merit or even its desirability, but with a view to exposing some tensions and difficulties inherent in its implementation within schools. These challenges will be summarized under six headings.

\section{Citizenship is tied to nationhood}

As many writers have noted, the idea of citizenship being defined "by birthplace and bloodline" is as old as the concept of citizenship itself and certainly pre-dates nationhood. As nations were defined, and re-defined, over the past few centuries, citizenship and nationhood have become inextricably linked and the history of citizenship has become a never-ending struggle within nations to determine just who should, and should not, claim the right to be called a citizen. It is a process that was born out of an exclusionary mindset and, to varying degrees, remains so today (Kingwell, 2000). The multiple impacts of globalization, however, have begun to seriously challenge the logic of citizenship's fixed association with nationhood in two fundamental ways: firstly, the increasing influence of supra-national bodies, including intergovernmental alliances and transnational corporations, has forced citizens to consider "the inconsequence and impotence of national sovereignties" (Ignatieff, 1984, p. 29) in determining their own fate; secondly, cross-border migration continues to transform many societies into complex pools of multiple ethnicities and nationalities, including many people with legitimate claims to more than one citizenship and yet many more who are denied access to the rights and privileges of a single citizenship.

As significant as the challenge to its hold on citizenship may be, the nation's grasp remains firm. It is the nation that confers a citizen's legal identity and instills, in so many ways, a sense of belonging. The process of schooling is a powerful force in this regard. Public education, through its choice of curriculum and its affirmation of cultural norms, has long been a purveyor of national values and ideals, a perpetuator of the national status quo rather than an agent of social change (Green, 1990). The traditional tenets of nationalism abound in schools today, from the deliberate focus on national history, geography, and culture (often to the exclusion of minority groups) in various curricula to the more opaque - but nonetheless powerful - influence of everyday life in the classroom that fails to recognize the connectedness of individuals to global systems. The fact that historical wars represent the world 
G. Pike

issue most frequently addressed in school suggests that students' preparation for contemporary global realities is hardly adequate (War Child Canada, 2006). If schools are to promote global citizenship as an ideal, the nationalist grip on schooling has to be loosened.

\section{Globalization does not nurture global citizenship}

The current forces of globalization are mounting the most robust challenge ever to the nation's hold on education (O'Sullivan, 1999). The needs of the global marketplace are profoundly influencing decisions over funding, curriculum, and teacher education, with a view to producing graduates who can compete in the global economy. The language of contemporary educational debate is telling: entrepreneurial skills are paramount, learning is defined by outcomes that are measurable, and a school's worth is judged by the quantifiable performance of its students as measured in international comparisons of achievement. Some of the global market's influences are unashamedly direct, such as the creeping privatization of public education through corporate involvement in educational decision making and schools' sponsorship deals with transnational corporations (Barlow \& Robertson, 1994). The ultimate products of such an educational process, suggests O'Sullivan (1999), are not citizens but consumers. Ironically, globalization, propelled by the relentless pursuit of economic growth, would seem to be working against the higher ideals of global citizenship.

As Saul (1995) has pointed out, corporate success in the global marketplace depends upon individuals' desire for inner comfort, for the satisfaction of desires through the consumption of goods and services. In affluent societies, consumerism has become a means by which we search for answers to a fundamental need, a sense of identity and belonging (O'Sullivan, 1999) - a need that lies at the very heart of citizenship. But, suggests Kingwell (2000), acquisition per se does not appear to lead to satisfaction and happiness:

We are, finally, happier not with more stuff but with more meaning: more creative leisure time, stronger connections to groups of friends, deeper commitment to common social projects, and a greater opportunity to reflect. In short, the life of the well-rounded person, including crucially the orienting aspect of life associated with virtuous citizenship (p. 218).

Virtuous citizenship, and the establishment of the "global moral community" (Dower, 2003), seem unlikely to be fuelled by the juggernaut of economic globalization, driven by the principles of profit, competition, and efficiency. As Osborne (1996) notes, the claims of citizenship - whether national or global in orientation - will largely be ignored while schooling is oriented to the imperatives of the global economy. 


\section{We don't "think globally"}

The maxim "think globally, act locally" resonates meaningfully among global citizenship advocates, combining in one pithy phrase the twin ideals at the root of their cause. Both, however, are problematic. More than two hundred years of intellectual and social development based on the mechanistic thinking of the rational-industrial world view have left their mark on our ability to conceptualize whole systems, to understand the big picture, to think globally. Our "loss of the cosmological sense", suggests O'Sullivan (1999), is at the root of many global crises we face, notably our inability to live sustainably within the limits of the planet's resources. The conceptual dimension of humankind, argues Head (1994), lags many decades behind evolution in the spatial and temporal dimensions, resulting in a "mental insularity" that blinds us to the global connections that are an integral feature of our contemporary lives. Increased connectedness, suggests Homer-Dixon (2003), has not resulted in greater understanding by those in the rich world of the everyday realities lived out by the poor majority: "Never before have we been so connected together on this planet and never before have we been so far apart in our realities" (p.15). More cynically, Kingwell (2000) contends that the forces of economic globalization demand that we remain disconnected, lest we should understand the less wholesome practices of the global labour market and decide to reduce our consumer spending. Global thinking is not in the interests of the global market.

The mechanistic world view pervades our school systems, thereby perpetuating difficulties in global thinking for at least another generation. The compartmentalization of knowledge into rigid disciplines, the favouring of analytical over synthetic or relational thinking skills, the dearth of global and holistic perspectives in practically every area of the curriculum, an obsession with the "hard" sciences and concurrent suspicion of the "soft" - and more integrative - arts; such priorities within education reflect our collective inability - and, perhaps, our lack of will - to think globally. My own research among global education practitioners suggests that even they find it difficult to release themselves from the shackles of world views which perceive nations and cultures as separate and distinct. Global education itself is imbued with mechanistic thinking (Pike, 2000). Until the dominant paradigm of schooling shifts towards more holistic visions, thinking globally - in its fullest sense will remain an ideal. Perhaps the intuitive global connectedness of today's youth, who shift loyalties easily from local to global and for whom technology has dissolved the former boundaries of their social networks, will mount a serious challenge to this paradigm. For the time being, however, schools appear to view such global connectedness more with suspicion and alarm than with encouragement. 
G. Pike

\section{We are less inclined to "act locally"}

The current interest in citizenship education in Western democracies would seem to stem, in part at least, from a concern over declining rates of participation in civil society, especially in the formal democratic process. Voter turnout at significant elections is falling; disenfranchisement - actual and perceived - among minority groups is rising; cynicism towards the political process and apathy among young people are widely reported. "I cannot recall a time," wrote Rollo May in 1972 (cited in Murphy, 1999, p. 13), “... when there was so much talk about the individual's capacities and potentialities and so little actual confidence on the part of the individual about his power to make a difference psychologically and politically." More than thirty years later, the phenomenon which May describes as "a paralysis of will" would seem to have intensified in established democratic societies, despite the significant victories by peoples' movements over totalitarian regimes in other parts of the world. Canadian youth may be increasingly worldminded but their frustration with their perceived lack of power to influence decision makers is also growing (O’Neill, 2004).

In the absence of any instruments of world government (which do not feature in most models of global citizenship), active participation at a local level is of paramount importance. National citizenship continues, albeit imperfectly, despite citizens lack of engagement, because the necessary civil and political structures are in place. Global citizenship is virtual; its essence depends upon the collective participation of citizens worldwide to give substance to an otherwise unrealizable ideal. The notion of "conspiracy" (Ferguson, 1982; Murphy, 1999) - the "breathing together" of separate groups with common visions in multiple localities - has been used to describe the character of participation required for global citizenship to thrive. But active civic participation requires the development and practice of a range of skills, especially if it is to extend beyond the superficial activities, such as fundraising for global causes that appear to be predominant in Canadian schools (Mundy, 2007). As Hart (1992) has noted, schools' attempts at encouraging active participation among students, and thereby refining the necessary skills of global citizenship, are often more tokenistic than meaningful.

\section{Post-nationalism is a luxury of the prosperous and secure}

Advocates of global citizenship, principally from Western industrialized countries with a recent history of prosperity and security, would do well to remind themselves that their nation's stability is built upon a legacy of nationalism. The cosmopolitan ideal is the privilege of those who no longer 
have to fight for their national identity (Ignatieff, 1993). We should also remember, with humility, that even within our well-ordered and seemingly inclusive nation states, regionalist and separatist passions frequently surface to challenge the model of citizenship that we have constructed. Racial conflict, violence against women, and persistent poverty are, in a different way, reminders that the benefits of national citizenship are not equally shared and still have to be fought for by some of our fellow citizens.

Tussles between nationalism and globalism are occurring in many education systems: Tye's (1999) survey of global education in 52 countries points to the persistence of nationalism as a major barrier to the spread of global education in many parts of the world. Global education initiatives in the Middle East would appear to have accommodated such tensions by incorporating nationalist and pan-Arab regionalist perspectives into global education classroom materials (Pike \& Selby, 1999). Merryfield's (2001) solution to the dilemma is to argue for a reconceptualization of global education with a view to examining the assumptions underlying the earlier, Eurocentric and Cold War frameworks and illuminating the world views of the poor, the oppressed and the marginalized. Only when we have examined "the pedagogy of imperialism," she contends, will global education become truly global. Such challenges to prevailing visions of global education serve to highlight the elitism that can easily suffuse the rhetoric of global citizenship education: for the countless millions of people worldwide who daily struggle for survival and the satisfaction of basic human rights, or for recognition of their cultural identity, global citizenship is not even on the agenda.

\section{Citizenship is an anthropocentric ideal}

The concept of civic culture originated in the need to accommodate the disparate needs and customs of diverse groups as they congregated in self-governing cities and then, over time, as these urban communities coalesced into national societies and empires (Boulding, 1988). Citizenship has its roots in urbanism. Throughout its history, the ideal of citizenship has had little to say about the conduct of humans in relation to other species, nor about the natural world in general. This anthropocentrism was heightened during the period of modernization as nature came to be regarded as a stock of abundant resources to be used in the great manufacturing centres in order to create goods for human consumption. Citizenship was about the right to enjoy the fruits of industrial societies, not about individuals' responsibilities towards the planet. Up to the present point in human history, the ideal of citizenship has been able to remain aloof from concerns about the natural environment, but it can be divorced no longer. Our "collective ecological blindness" (Wackernagel \& Rees, 1996) has resulted in unsustainable patterns 
of living that are already wreaking havoc on ecological systems worldwide. Though urbanization continues to spread around the planet, no longer can citizens feel secure in their urban environments from the perils of climate change, deforestation, pollution, and loss of species. In fact, urbanization goes hand in hand with economic growth and the development of societies that are placing greater demands on the earth's resources.

Quite naturally, citizenship education has traditionally reflected this anthropocentric stance; the dimension of environmental citizenship remains largely unexplored. Global education, too, has been critiqued from a biocentric perspective (Selby, 2000), based on the argument that interpretations of concepts such as interdependence are still infused with mechanistic rather than holistic thinking. Thus, nations and cultures - though regarded as dependent on each other - are not viewed as part of the entire biotic community. In focusing on global citizenship, we have the opportunity to open up the citizenship debate, to argue that the rights and responsibilities of citizens should be conceptualized within the context of the interdependent relationship of human beings and their environments. To fail in this task will be to seriously limit the freedoms and choices of future citizens. In this regard, there would be merit in a cross-fertilization of ideas between the two contemporary movements of education for global citizenship and education for sustainable development.

\section{Some Possible Dimensions of an Ethos of Global Citizenship in Education}

Notwithstanding the problems outlined above, the ideal of global citizenship education is worth further exploration. The concept of citizenship has proven to be immensely adaptable over time, changing to meet various geographical, political, and cultural pressures, moving from an exclusionary force towards ever greater inclusion. In an era of human history in which global interdependence is one of the defining characteristics, it is time for our understanding of citizenship - and citizenship education - to shift once more, to expand as an ideal that more closely befits the world we have created. More pragmatically, in an era in which the major engines of economic power, transnational corporations, have extended their allegiance and their influence beyond the borders of a single nation, it is surely time for global consumers to reexamine the responsibilities and privileges of living in a global community.

Expansion does not necessitate dismantling the present construction of citizenship: the arguments presented here do not call for an end to national citizenship, nor for the institution of world governance. Rather, they challenge educators to acknowledge the ever-changing patterns of relationships among human communities, and between humans and their environments, and to help students explore the implications of such trends in terms of their rights and 
responsibilities, their allegiances and loyalties, and their opportunities for meaningful participation. Citizenship, in a constitutional sense, may continue to be granted by the nation state for a long time to come, but that should not negate the exciting possibilities for the development of an ethos of global citizenship in our schools. In such a suggestion is an acceptance that, despite globalization, it is the nation that will continue to provide citizens with their primary sense of belonging. The challenge, however, is to imbue the concept of citizenship with an ethos - a set of moral principles and codes of conduct that is global in its scope. While the state will confer the constitutional rights and duties of citizenship, education should play a critical role in expanding young citizens' understanding of the responsibilities, and potential pleasures, of living in a global community. The result will be active national citizens with an informed global conscience.

Mindful of the problematic concept of global citizenship, the following six dimensions would seem to be critical to the development of that ethos. They are offered as starting points, not an exhaustive list, for the discussion and evaluation of present and future models of global citizenship education.

1. An expansion of loyalty

- an acceptance and valuing of multiple identities and loyalties, including family, community, region, bio-region, country, continent, species, and planet;

- an understanding that co-existent loyalties may conflict and a determination to use informed judgment in the resolution of such conflicts;

- an understanding that loyalties may shift over time, that identity "is no museum piece, sitting stock-still in a display case, but rather the endlessly astonishing synthesis of the contradictions of everyday life" (Galeano, cited in Murphy, 1999, p. 147).

2. A critical appraisal of both nationalism and globalism

- a predisposition to critically assess the claims and conduct of national governments and transnational agencies from the perspectives of justice, equity, and human rights;

- an understanding that global interdependence often results in inequitable benefits and outcomes;

- an understanding that individual consumer decisions have multiple impacts in the global marketplace.

3. The development of global thinking

- development of the skills of synthetic and relational thinking, to aid the process of seeing connections and relationships between various phenomena; 
G. Pike

- development of futures thinking skills, to provide insights into the interrelationship of past, present, and future;

- $\quad$ a deep understanding of the concept of sustainability and of its implications for present lifestyles and behaviour.

4. Understanding citizenship as "doing," not just "being” or "knowing"

- an understanding that action and participation are the essence of citizenship;

- an understanding of the multiple roles that each citizen plays in the global community;

- $\quad$ refinement of the skills and attitudes required to engage in constructive social change at local, regional, national, and transnational levels.

5. Acceptance of the moral responsibilities of global citizenship

- $\quad$ an understanding of the consequences of imperialism and of the present struggles for national identity taking place around the world;

- an understanding of the effects of the attitudes and lifestyles of the affluent minority on the choices and freedoms of the poor, the dispossessed, and the disadvantaged around the world;

- a commitment to a continuous assessment of personal values and behaviour with a view to increasing actions that serve the needs of others.

6. Understanding citizens' roles in determining the future health of the planet

- an understanding of the interdependence of all life forms and of the importance of bio-diversity to the health of the planet;

- $\quad$ an understanding that the functioning of the planet is increasingly dependent upon human wisdom and decision making;

- development of the "knowing, caring and practical competence ... of ecological literacy” (Orr, 1992, p. 92).

\section{References}

Bahá'í International Community. (1993). World citizenship: A global ethic for sustainable development. Retrieved August 6, 2007 from http:// statements.bahai.org/93-0614.htm

Banks, J. A. (2001). Cultural diversity and education: Foundations, curriculum and teaching. Boston: Allyn and Bacon.

Barlow, M., \& Robertson, H.-J. (1994). Class warfare: The assault on Canada's schools. Toronto, Ontario, Canada: Key Porter Books.

Boulding, E. (1988). Building a civic culture: Education for an interdependent world. Syracuse, NY: Syracuse University Press. 
Canadian Council for International Co-operation. (1996). Global citizenship: A new way forward. Report from the CCIC Task Force on building public support for sustainable development. Ottawa, Ontario, Canada: CCIC.

Cogan, J. J. \& Derricott, R. (1998). Citizenship for the 21st century: An international perspective on education. London: Kogan Page.

Dower, N. (2003). An introduction to global citizenship. Edinburgh, Scotland: Edinburgh University Press.

Ferguson, M. (1982). The Aquarian conspiracy: Personal and social transformation in the 1980s. New York: Granada.

Green, A. (1990). Education and state formation: The rise of educational systems in England, France and the USA. New York: St. Martin's Press.

Griffith, R. (1998). Educational citizenship and interdependent learning. London: Jessica Kingsley Publishers.

Hart, R. (1992). Children's participation: From tokenism to citizenship. Innocenti Essays No 4. Florence, Italy: UNICEF International Child Development Centre.

Head, I. (1994). Knowledge in the third dimension. A world turned upside down. Global Education, 2, 2-5.

Heater, D. (1984). Peace through education. The contribution of the Council for Education in World Citizenship. London: Falmer Press.

Heater, D. (1990). Citizenship. The civic ideal in world history, politics and education. London: Longman.

Hébert, Y. (1997, June) Citizenship education: Yes, but how? Towards a pedagogy of social participation and identity formation. Paper presented at the Canadian Society for the Study of Education conference, St. John's, Newfoundland, Canada.

Homer-Dixon, T. (2003). Human adaptation and the ingenuity gap. Brock Education, 12(2), 1-22.

Ignatieff, M. (1984). The needs of strangers. London: Penguin Books.

Ignatieff, M. (1993). Blood and belonging: Journeys into the new nationalism. Toronto, Ontario, Canada: Viking.

Kingwell, M. (2000). The world we want: Virtue, vice and the good citizen. Toronto, Ontario, Canada: Viking.

Lynch, J. (1992). Education for citizenship in a multicultural society. London: Cassell.

Merryfield, M. M. (2001). Moving the center of global education: From imperial world views that divide the world to double consciousness, contrapuntal pedagogy, hybridity and cross-cultural competence. In W. B. Stanley (Ed.), Critical issues in social studies research for the 21st century (pp. 179-208). Greenwich, CT: Information Age Publishing.

Mundy, K. (2007). Charting global education in Canada's elementary schools. Toronto, Ontario, Canada: UNICEF Canada.

Murphy, B. K. (1999). Transforming ourselves, transforming the world: An open conspiracy for social change. London: Zed Books.

Noddings, N. (Ed.). (2005). Educating citizens for global awareness. New York: Teachers College Press.

O’Neill, M. (2004). New horizons: Engaging Canadians as active global citizens. Ottawa, Ontario, Canada: Canadian Council for International Co-operation.

Orr, D. W. (1992). Ecological literacy: Education and the transition to a postmodern world. Albany, NY: State University of New York Press. 
G. Pike

Osborne, K. (1996). Education is the best national insurance: citizenship education in Canadian schools, past and present. Canadian and International Education, 25(2), 31-58.

O'Sullivan, E. (1999). Transformative learning: Educational vision for the 21st century. New York: Zed Books.

Oxfam. (2006). Education for global citizenship: A guide for schools. Oxford, GB.

Pike, G. (2000). Global education and national identity: In pursuit of meaning. Theory into Practice, 39(2), 64-73.

Pike, G. \& Selby, D. (1999). Global education: Making basic learning a child-friendly experience. Amman, Jordan: UNICEF Regional Office for the Middle East and North Africa.

Saul, J. R. (1995). The unconscious civilization. Concord, Ontario, Canada: Anansi.

Selby, D. (1994). Kaleidoscopic mindset: New meanings within citizenship education. Global Education, 2, 20-31.

Selby, D. (2000). A darker shade of green: The importance of ecological thinking in global education and school reform. Theory into Practice, 39(2), 88-96.

Tye, K. A. (1999). Global education: A worldwide movement. Orange, CA: Interdependence Press.

Wackernagel, M. \& Rees, W. (1996). Our ecological footprint: Reducing human impact on the earth. Gabriola Island, British Columbia, Canada: New Society Publishers.

War Child Canada. (2006). The war child Canada youth opinion poll. Toronto, Ontario, Canada: War Child Canada. 